Postgraduate Bosowa University Publishing (PBUP)
Indonesian Journal of Business and Management
e-ISSN: $2460-3767 \quad p$-ISSN: $2656-6885$
Inttps://postgraduate.universitasbosowan
JOURAL

\title{
KEPEMIMPINAN TRANFORMASIONAL: DETERMINAN FAKTOR KINERJA KARYAWAN HOTEL HARPER PERINTIS BY ASTON DI KOTA MAKASSAR
}

\section{Transformational Leadership: Determination Factors of the Performance of Harper Perintis by Aston Employees in Makassar City}

\author{
Ardiyansyah Goeliling ${ }^{1}$, Sukmawati Marjuni², Miah Said ${ }^{2}$ \\ ${ }^{1}$ Mahasiswa Magister Manajemen Universitas Universitas Bosowa \\ ${ }^{2}$ Program Studi Manajemen Program Pascasarjana Universitas Bosowa \\ Email: creaturehouse8427@gmail.com
}

Diterima: 10 Januari 2020/Disetujui: 01 Juni 2020

\begin{abstract}
ABSTRAK
Kinerja karyawan merupakan cerminan dari kinerja karyawan berkualitas tinggi dan rendah yang akan mendukung produktivitas organisasi. Jenis penelitian yang digunakan dalam penelitian ini adalah pendekatan kuantitatif. Studi kuantitatif digunakan untuk menguji sampel populasi dengan menganalisis metode uji $n=$ Total Sampel $L=N$ ukuran populasi, dan E= Tetapkan konstan atau persentase yang sesuai. Dengan hasil ini, karyawan memiliki masalah dengan kepemimpinan transformasional yang diawasi oleh karyawan Harper By Aston. Hubungan antara kepemimpinan transformasional dan kinerja karyawan diperkuat dari hasil analisis regresi. Hasil dari hasil tes berutang penurunan yang signifikan dalam kemungkinan kepemimpinan transformasional dalam kinerja 0104 dari kesalahan terkecil untuk Clea Rance $\alpha=0,05$.
\end{abstract}

Kata Kunci: Kepemimpinan, Transformasional, Kinerja Karyawan, Makassar

\begin{abstract}
Employee performance is a reflection of high and low-quality employee performance that will support organizational productivity. The type of research used in this study is a quantitative approach. Quantitative studies are used to test population samples by analyzing the test method $n=$ Total Sample $L=N$ population size, and $E=$ Set constant or the appropriate percentage. With this result, employees have a problem with the transformational leadership style that is supervised by Harper by Aston employees. The relationship between transformational leadership and employee performance is strengthened from the results of the regression analysis. The results from the test results owe a significant decrease in the likelihood of transformational leadership in the 0104 performance of the smallest error for Clea Rance $\alpha=$ 0.05 .
\end{abstract}

Keywords: Leadership, Transformational, Employee Performance, Makassar

\section{PENDAHULUAN}

Masalah sumber daya manusia (SDM) masih menjadi sorotan dan landasan bagi organisasi untuk bertahan hidup di era globalisasi. SDMmemainkan peran sentral dalam setiap kegiatan organisasi. Meski didukung oleh fasilitas dan infrastruktur serta sumber dana yang berlebihan, tetapi tanpa dukungan SDM yang andal, kegiatan organisasi tidak akan bisa dilakukan dengan baik. Karyawan perusahaan adalah aset perusahaan yang penting bagi mereka memberikan pengaruh besar untuk membuat setiap lingkungannya (organisasi) untuk mencapai tujuan.

Organisasi dan karyawan adalah dua elemen yang saling membutuhkan dan tidak dapat dipisahkan satu sama lain. Karyawan umumnya memiliki kemampuan untuk membuat kontribusi positif bagi organisasi, sumber daya sehingga daya manusia adalah salah satu faktor kunci dalam satu organisasi upaya untuk mencapai tujuannya. Keberlanjutan organisasi terutama ditentukan oleh kinerja karyawan yang baik, sehingga penting untuk mengevaluasi kinerja karyawan sehingga organisasi 
mengetahui bahwa karyawan mereka berkontribusi terhadap pertumbuhan perusahaan.

Bass (1985) menjelaskan bahwa pemimpin transformasi membuat perubahan signifikan bagi pengikut dan organisasi mereka dan agen perubahan yang mencoba membuat perubahan organisasi sehingga mereka dapat mencapai kinerja maksimal di masa depan. Kepemimpinan transformasional di dasar karyawan lebih dari apa yang biasanya dilakukan, di lain kata-kata itu dapat menambah kredibilitas atau bawah sadar rasa percaya diri yang akan mempengaruhi pekerjaan perbaikan.

Meski didukung oleh fasilitas dan infrastruktur serta sumber dana yang berlebihan, tetapi tanpa dukungan SDM yang andal, kegiatan organisasi tidak akan bisa dilakukan dengan baik. Ini menunjukkan bahwa penguasaan adalah kunci yang harus dipertimbangkan semua orang. sebagai poin penting, SDM akan menentukan keberhasilan pelaksanaan kegiatan organisasi. Tuntutan organisasi untuk memperoleh, mempertahankan, dan memelihara SDM berkualitas tinggi semakin sejalan dengan dinamika lingkungan yang terus berubah. Menghadapi persaingan bisnis saat ini semakin ketat, karyawan dituntut untuk terus meningkatkan sehingga badan usaha masih ada, sehingga harus berani untuk wajah yaitu mengubah wajah dan memenangkan kompetisi.

Menyadari kinerja sangat penting untuk manajemen mengevaluasi kinerja untuk mencapai yang perusahaan tujuan. Mundarti (2007) berpendapat bahwa manusia adalah pendorong dan penentu kursus organisasi, sehingga kepemimpinan diperlukan untuk menentukan kinerja karyawan. Kinerja (performance) berarti pekerjaan dapat dicapai oleh seseorang atau sekelompok orang dalam organisasi, sesuai dengan wewenang dan tanggung jawab dalam konteks upaya mencapai tujuan organisasi yang dimaksud adalah sah tidak merusak hukum dan sesuai dengan etika moral (Sedarmayanti 2007).

Semua dimensi dan indikasi di atas jika dilakukan dengan baik akan memaksimalkan peran pemimpin dalam perusahaan. Pemimpin diharapkan untuk meningkatkan dan mendukung kinerja karyawan mereka dengan memotivasi dan merangsang ide-ide kreatif, merawat karyawan mereka dan menjadi pemimpin yang dilindungi dan dihormati dari semua karyawan.

\section{METODE}

Penelitian kuantitatif merupakan cara yang lebih penting untuk mengukur aspek objektif dari fenomena sosial. Data kuantitatif yaitu, data dalam negeri dengan jumlah total dapat dihitung. Dalam penelitian ini, tujuan dari data kuantitatif jumlah karyawan, hasil penelitian analisis data kualitatif, yaitu data yang tidak dapat distate dalam bentuk angka. Dalam penelitian ini, data kualitatif disajikan sebagai gambaran umum dari lokasi penelitian.
Studi khusus ini, dilakukan di Harper Pioneer oleh Aston. Periode penelitian adalah sekitar 2 (dua) bulan, yang berlangsung dari Desember 2019 hingga Januari 2020. Populasi penelitian ini adalah Harper Pioneer oleh karyawan Aston-Makassar yang berlokasi di Km 15 Makassar No 14 Desa Pai, Kabupaten Biringkanaya, Kota Makassar, Provinsi Sulawesi Selatan. Hotel ini mempekerjakan sekitar 100 karyawan untuk memenuhi kriteria ini, dan spesifikasi sampel dalam penelitian ini adalah sepenuhnya sampel atau sensus

\section{HASIL DAN PEMBAHASAN}

Kinerja karyawan memainkan peran penting dalam sebuah organisasi karena kinerja setiap karyawan adalah kontribusi terhadap kinerja masing-masing fungsi organisasi dan di gilirannya, yang kinerja memberikan kontribusi fungsi organisasi dengan kinerja kinerja organisasi (Balasundaram, 2005). Kinerja karyawan dalam suatu organisasi dapat memimpin organisasi saya telah dibunuh oleh mengamankan tujuan (Yunxia et al., 2006).

Kinerja karyawan adalah penampilan karyawan dalam hal kuantitas dan kualitas dan sebagai ukuran atau ukuran seberapa baik karyawan melakukan tugas dan tanggung jawab yang dapat dilakukan perusahaan kinerja karyawan yang tinggi akan mendukung produktivitas organisasi. Kinerja dapat berupa kinerja individu atau kelompok. Kinerja tinggi, yaitu, karyawan yang melakukan pekerjaan mereka dengan semangat dan antusiasme untuk mencapai tujuan yang telah ditetapkan sebelumnya. Menurut pandangan Henry Simamira (Mangkuenegara, 2010) kinerja dipengaruhi oleh tiga faktor yakni faktor individu termasuk kemampuan dan keahlian, latar belakang, demografi. Faktor psikologis, termasuk para persepsi sikap (attitude), kepribadian, belajar, motivasi. Faktor organisasi, termasuk sumber daya, kepemimpinan, penghargaan. Faktor yang disebutkan tidak dapat berdiri sendiri tetapi sebagai satu kesatuan yang sedang terkait satu sama lain, sehingga dapat disebut bahwa karyawan tidak hanya dipengaruhi oleh satu faktor.

Untuk manajemen SDM melalui suatu rasio kinerja dapat memiliki langsung dan efisien efek yang terkait dengan organisasi. Dalam bisnis dunia yang penerapan kepemimpinan yang satu dapat mempengaruhi sikap dan perilaku bawahan mereka Keberhasilan dipengaruhi oleh pemimpin, yang efektif kepemimpinan perusahaan (Ahmad et al., 2020). Seberapa baik dan buruk yang dapat sebuah ffect seseorang dapat mempengaruhi kinerja karyawan secara langsung dan tidak langsung. Selain menjadi pemimpin, karyawan juga menentukan keberhasilan perusahaan (Ackoff, 1999). Karyawan dapat membuat perusahaan mereka sukses dengan kinerja, hasil, dan tujuan mereka. Pemimpin transformasional adalah pemimpin yang mengarahkan pengikut mereka untuk kepentingan pribadi organisasi dan dapat memiliki efek mendalam pada pengikut mereka. Dia memberi perhatian pada kebutuhan pengembangan pengikut diri, 
mengubah kesadaran para pengikut akan masalah yang ada dengan bantuan orang lain melihat masalah lama dengan cara baru, dan bisa menyenangkan serta memberi Anda inspirasi agar pengikut menjadi mampu bekerja keras untuk mencapai tujuan bersama (Robbins dan Judge, 2008).

Kepemimpinan transformasional adalah proses untuk orang lain dan membuat koneksi yang meningkatkan motivasi dan moral pemimpin dan pengikut. Pemimpin seperti ini memperhatikan kebutuhan dan motif pengikutnya dan berusaha membantu pengikutnya mencapai potensi penuh mereka. Kepemimpinan adalah transformasi murni, yaitu kepemimpinan sosial dan kepedulian untuk kebaikan bersama. Pemimpin transformasional sosial menjadi lebih besar untuk kepentingan orang lain. Pemimpin transformasi adalah kemampuan untuk menginspirasi dan memotivasi pengikutnya untuk dapat menghasilkan hasil yang jauh lebih besar dari yang direncanakan dan mendapat rumah. Dari definisi di atas, yang kepemimpinan transformasional adalah pemimpin cara dapat mempengaruhi bawahannya untuk meningkatkan kinerja karyawan mereka untuk mencapai tujuan organisasi secara efektif dan efisien.

Kepemimpinan transformasional menggambarkan empat karakteristik utama, yaitu: yang idealisasi pengaruh, motivasi inspirasional, wawasan individu, dan stimulasi intelektual (Bass dan Avolio, 1993; Bass, 1997; Bass et al, 2003). Bass dan Avolio (1993) memperkenalkan empat dimensi kepemimpinan transformasional yang dikenal sebagai konsep "4I" pada tahun 1994. Bass menginstruksikan para pemimpin transformasional untuk mendapatkan kepercayaan, rasa hormat, dan kekaguman dari pengikut mereka. Berikut ini adalah dimensi dan indikasi kepemimpinan transformasional yang dirujuk dalam penelitian ini: (1) pengaruh yang tepat, pemimpin harus menjadi contoh yang baik, karyawan dapat mengikuti, untuk menghasilkan rasa hormat dan kepercayaan pada pemimpin., (2) motivasi Inspirational, pemimpin harus mampu memberikan motivasi, dan target yang jelas untuk pencapaian oleh karyawan, (3) Intelektual simulation, pemimpin harus mampu merangsang karyawan untuk datang dengan ide-ide dan ide-ide baru, pemimpin juga harus melayani pemecah masalah pekerjaan mereka dan berinovasi di mana saja, dan (4) pertimbangan individu, pemimpin perlu penuh perhatian, mendengarkan keluhan, dan memahami kebutuhan karyawan. Semua dimensi ini, jika diterapkan dengan benar, akan membantu meningkatkan peran pemimpin dalam perusahaan.

Model untuk menggambarkan tanggapan responden terhadap item dari penilaian kuesioner pada variabel penelitian menggunakan persentase. Berikut ini adalah hasil dari pengolahan kuesioner tanggapan responden terhadap indikator yang meliputi pertanyaan tentang kuesioner serta perhitungan skor untuk variabel dari kepemimpinan, komunikasi, kompetensi, dan kinerja karyawan.
Variabel Kepemimpinan $\left(\mathrm{X}_{1}\right)$ dalam penelitian ini diukur melalui 9 pernyataan yang menampilkan dimensi dan indikator variabel. Dalam kuesioner, 9 pertanyaan dalam variabel dimensi kepemimpinan otokratis, birokrasi kepemimpinan, kepemimpinan diplomatik, $\mathrm{g}$ adalah elemen kepemimpinan dan kepemimpinan leade kebebasan. Setiap ukuran memiliki beberapa indikator yang ditunjukkan dalam pertanyaan yang dapat dilihat di bawah Tabel 1 :

Tabel 1 Distribusi Responden tentang Variabel Kepemimpinan (X1)

\begin{tabular}{|c|c|c|c|c|c|c|c|}
\hline \multirow{2}{*}{ No } & \multirow{2}{*}{ Pertanyaan } & \multicolumn{5}{|c|}{ Tanggapan Responden } & \multirow{2}{*}{ Skor } \\
\hline & & STS & TS & $\mathrm{N}$ & $\mathrm{S}$ & SS & \\
\hline 1 & $\begin{array}{l}\text { Pemimpin memberi alasan } \\
\text { yang jelas untuk pekerjaan } \\
\text { yang diberikan kepadanya }\end{array}$ & 0 & 0 & 3. & 63 & 34 & 100 \\
\hline 2 & $\begin{array}{l}\text { Pemimpin memperhatikan } \\
\text { masalah karyawan }\end{array}$ & 0 & 0 & 2. & 64 & 34 & 100 \\
\hline 3 & $\begin{array}{l}\text { Pemimpin selalu ada ketika } \\
\text { karyawan menghadapi hal- } \\
\text { hal sulit di tempat kerja }\end{array}$ & 0 & 1. & 6. & 52 & 41 & 100 \\
\hline 4 & $\begin{array}{l}\text { Pemimpin mendorong dan } \\
\text { mendukung karyawan } \\
\text { mereka dalam belajar. }\end{array}$ & 0 & 0 & 1. & 48 & 51 & 100 \\
\hline 5 & $\begin{array}{l}\text { Pemimpin menginspirasi } \\
\text { karyawan untuk melihat } \\
\text { masalah sebagai peluang } \\
\text { belajar. }\end{array}$ & 0 & 0 & 3. & 53 & 44 & 100 \\
\hline 6 & $\begin{array}{l}\text { Pemimpin dapat terbuka } \\
\text { terhadap visi karyawan } \\
\text { mereka sehingga mereka } \\
\text { tidak terjebak dalam satu hal }\end{array}$ & 0 & 0 & 4. & 61 & 35 & 100 \\
\hline 7 & $\begin{array}{l}\text { Para pemimpin saya } \\
\text { mendorong karyawan untuk } \\
\text { memecahkan masalah } \\
\text { dengan pemikiran inovatif. }\end{array}$ & 0 & 0 & 10. & 47 & 43 & 100 \\
\hline 8 & $\begin{array}{l}\text { Para pemimpin saya } \\
\text { menyediakan fasilitas untuk } \\
\text { mendukung karyawan } \\
\text { mereka }\end{array}$ & 0 & 1. & 9. & 53 & 37 & 100 \\
\hline 9 & $\begin{array}{l}\text { Para pemimpin saya } \\
\text { memberikan contoh yang } \\
\text { baik untuk karyawan kami }\end{array}$ & 0 & 0 & 6. & 49 & 45 & 100 \\
\hline & Rata-rata & 0 & 0,2 & 4.8 & 54,4 & 40.4 & 100 \\
\hline
\end{tabular}

Sumber: Data diolah, 2020.

Data yang telah diproses dengan cara buzzer $1 \mathrm{di}$ atas, menunjukkan bahwa mayoritas responden setuju dengan persentase $54,4 \%$ dari $100 \%$, dan surplus menjawab sangat Setuju (SS) sebesar 40,4\%, Netral (N) 4,8\%, Tidak setuju (TS) sebesar 0,2\% dan Sangat Tidak setuju (STS) sebesar 0\%. Distribusi Responden Jawaban Tentang Kinerja Karyawan (Y) variabel kinerja (Y) dalam risalah ini sebagai diukur dengan 6 pernyataan yang memberikan indikasi variabel. Hasil tanggapan terhadap variabel kinerja karyawan dijelaskan di bawah ini dalam Tabel 2.

Tabel 2 Distribusi Responden pada Variabel Kinerja (Y)

\begin{tabular}{lcccccc}
\hline \multirow{2}{*}{ No $\quad$ Pertanyaan } & \multicolumn{5}{c}{ Tanggapan Responden } \\
\cline { 2 - 6 } & $\begin{array}{c}\text { STS } \\
(\%)\end{array}$ & $\begin{array}{c}\text { TS } \\
(\%)\end{array}$ & N $(\%)$ & $\begin{array}{c}\text { S } \\
(\%)\end{array}$ & $\begin{array}{c}\text { SS } \\
(\%)\end{array}$ & \\
\hline 1 Pekerjaan yang saya & 0 & 3. & 11. & 57 & 29 & 100
\end{tabular}




\begin{tabular}{lllllll}
$\begin{array}{l}\text { lakukan dapat dilakukan } \\
\text { sesuai dengan harapan }\end{array}$ & & & & & & \\
$\begin{array}{l}\text { 2Saya dapat } \\
\text { menyelesaikan semua } \\
\text { pekerjaan yang disajikan } \\
\text { tepat waktu }\end{array}$ & 0 & 1. & 18 & 59 & 22. & 100 \\
$\begin{array}{l}\text { 3Saya memiliki } \\
\text { pengetahuan tentang } \\
\text { tugas yang Anda berikan }\end{array}$ & 0 & 0 & 16. & 56 & 28 & 100 \\
$\begin{array}{c}\text { 4Pekerjaan yang saya } \\
\text { temukan diterima dengan } \\
\text { baik }\end{array}$ & 0 & 1. & 8 & 59 & 32 & 100 \\
$\begin{array}{c}\text { 5Saya pasti bekerja sesuai } \\
\text { jam kerja saya }\end{array}$ & 0 & 1. & 14 & 53 & 32 & 100 \\
$\begin{array}{c}\text { 6Saya bisa menyelesaikan } \\
\text { sesuatu tanpa bantuan } \\
\text { orang lain }\end{array}$ & 0 & 9. & 12. & 31 & 15. & 100 \\
$\quad$ Rata-rata & 0 & 0 & 16. & 18.8 & 35 & 27.5 \\
\hline
\end{tabular}

Sumber: Data diolah, 2020.

Data yang diproses pada Tabel 2 di atas, terlihat bahwa mayoritas responden menjawab Setuju (S) dengan persentase $35 \% 100 \%$, yang lain menjawab Setuju Kuat (SS) 27,5\%, Netral (N) sebesar 18,8\% tidak setuju (TS) dan $16 \%$ tidak setuju (STS) dengan $0 \%$.

Model untuk menggambarkan para informasi jawaban responden untuk item dari pernyataan kuesioner dalam variabel penelitian adalah untuk menggunakan persentase. Berikut ini adalah hasil dari pengolahan tanggapan kuesioner dari responden dengan indikasi barang - barang yang dimaksud kuesioner dan juga untuk menghitung skor variabel dari kepemimpinan, komunikasi, kompetensi dan kinerja karyawan dengan Harper Hotel Aston Makassar.

Pengujian yang dilakukan pada risalah meliputi deskriptif statistik, data uji kualitas (uji validitas dan reliabilitas), uji asumsi klasik (uji normalitas, uji heteroskedastisitas, dan tes linearitas ), analisis regresi linier, dan uji hipotesis (uji Pearson dan koefisien analisis penentuan). Cara mengelompokkan data ini adalah sebagai berikut:

$$
\begin{array}{ll}
\text { Tinggi } & =\text { rata-rata }+\mathrm{SD} \leq \mathrm{X} \\
\text { Sedang } & =\text { rata-rata }-\mathrm{SD} \leq \mathrm{X}<\text { rata-rata }+\mathrm{SD} \\
\text { Basic } & =\mathrm{X}<\text { mean }-\mathrm{SD}
\end{array}
$$

Variabel yang digunakan dalam penelitian ini meliputi kepemimpinan, komunikasi, kecerdikan dan kinerja karyawan yang muncul dari statistik deskriptif seperti:

Tabel 3 Hasil Analisis Deskriptif

\begin{tabular}{lccccc}
\hline & N & Setidaknya & Buka & $\begin{array}{c}\text { Itu } \\
\text { berarti }\end{array}$ & $\begin{array}{c}\text { Std. } \\
\text { Deviasi }\end{array}$ \\
\hline Kepemimpinan & 100 & 31 & 45 & 39.09 & 3.975 \\
\hline Valid N & 100 & & & & \\
\hline Sumber: Data diolah, 2020. & & & &
\end{tabular}

Tabel 3 menunjukkan bahwa sementara kepemimpinan bervariasi yang transformasional, berarti minimal responden adalah 31 dan yang maksimum adalah 45, dengan rata-rata 39,09 jawaban dan standar deviasi 3.975 .

\section{1) Hasil Uji Validasi}

Uji Validasi bertujuan untuk mengukur validitas atau kelengkapan kuesioner. Kuesioner dapat valid jika pertanyaan dalam kuesioner dapat mengungkapkan apa yang akan diukur dengan kuesioner. Hasil tes yang valid telah mengatakan kebenaran bahwa dalam probabilitas nilai lebih kecil dari 0,05 jika nilai probabilitas lebih besar dari 0,05 menunjukkan bahwa pernyataan item yang tidak valid. Dasar-dasar pengambilan keputusan adalah:

Jika $r$ hitung $>\mathrm{r}$ tabel = klaim dianggap benar

Jika $\mathrm{r}$ hitung $<\mathrm{r}$ tabel $=$ pernyataan dianggap tidak valid

Uji validitas dengan membandingkan nilai hitung $r$ dengan tabel $r$ dengan derajat kebebasan $(d f)=n-2$ (n adalah jumlah sampel yang membentuk regresi). Angka penelitian ini menggunakan 100 responden, penentuan ( $\mathrm{p}$ df) $=100-2=98$. Dengan tingkat signifikansi 5\%, yang meja $\mathrm{r}$ adalah 0,2516 . Uji $\mathrm{v}$ validitas dihitung dengan membandingkan jumlah $\mathrm{r}$ ( korelasi item-total korelasi ) dengan tabel ketika tabel $r>r$ tabel (pada taraf signifikansi 5\%) maka pernyataan tersebut menjadi valid. Hasil tes adalah sebagai berikut:

Tabel 4 Uji Validasi

\begin{tabular}{cccc}
\hline $\begin{array}{c}\text { Item } \\
\text { pertanyaan }\end{array}$ & R hitung & R tabel & Informasi \\
\hline & Kepemimpinan Transformasional (X 1 ) & \\
1 & 0,677 & .284 & Tersedia \\
2 & 0,702 & .284 & Tersedia \\
3 & 0,624 & .284 & Tersedia \\
4 & 0,631 & .284 & Tersedia \\
5 & 0,667 & .284 & Tersedia \\
6 & 0,677 & .284 & Tersedia \\
7 & 0,679 & .284 & Tersedia \\
8 & 0,575 & .284 & Tersedia \\
9 & 0,685 & .284 & Tersedia \\
\hline
\end{tabular}

Sumber: Hasil Analisis, 2020.

Hasil ini, data yang diperoleh mengungkapkan bahwa dari 33 item kuesioner yang diberikan kepada 100 responden, nilai Korelasi Pearson lebih besar dari 0,284 (tabel r) valid. Ini menunjukkan bahwa setiap pertanyaan yang diajukan oleh responden dari setiap pertanyaan ke masing-masing variabel dalam penelitian ini dapat mengukur apa yang diinginkan responden.

2) Uji Asumsi Klasik

Tes asumsi klasik yang digunakan dalam penelitian ini meliputi tes normalitas untuk linearitas dan heteroskedastisitas tes. Berikut ini menjelaskan setiap tes dari asumsi klasik di masing-masing variabel penelitian. The normalitas uji dilakukan untuk melihat apakah nilai tersebut terdistribusi secara normal. Uji normalitas untuk menguji salah satu asumsi dasar dari analisis regresi ganda, yaitu bahwa yang independen dan dependen variabel harus terdistribusi normal atau dekat dengan yang normal (Ghozali, 2011). Uji statistik yang digunakan untuk menguji asumsi normalitas adalah 
dengan menggunakan uji normalitas Kolmogorov Smirno. Metode uji normal untuk distribusi data dilakukan dengan melihat signifikansi dari variabelvariabel ini, jika signifikansi lebih besar dari 0,05 pada tingkat alpha signifikansi 5\%, maka distribusi data normal. Hasil tes yang diperoleh adalah sebagai berikut:

Tabel 5 Uji Normalitas

\begin{tabular}{lcc}
\hline Membangun & Sig. & Kesimpulan \\
\hline $\mathrm{X} 1$ & 0,285 & Biasa \\
\hline Sumber: Hasil Analisis, 2020 & &
\end{tabular}

Ini dilakukan bahwa semua kemungkinan normal. Hal ini dapat dilihat dari tingkat signifikansi) semua di atas 0,285 . itu disimpulkan bahwa yang transformasional variabel kepemimpinan biasanya tersebar, sehingga mereka dapat dianalisa lebih lanjut.

3) Uji Multikolinearitas

Multikolinearitas Uji kebutuhan s untuk mendeteksi keberadaan dari masalah $\mathrm{s}$ dan dapat dilakukan dengan melihat nilai yang Toleransi dan faktor variasi inflasi (VIF) dan besarnya dari korelasi dari variabel. (Melekat ke dalam halaman berikutnya).

Tabel 6 Hasil Uji Statistik

\begin{tabular}{|c|c|c|c|c|c|c|c|c|}
\hline \multirow{2}{*}{\multicolumn{2}{|c|}{ Model }} & \multicolumn{2}{|c|}{$\begin{array}{c}\text { Unstandardized } \\
\text { Coefficients }\end{array}$} & \multirow{2}{*}{$\begin{array}{c}\text { Standardized } \\
\text { Coefficients } \\
\text { Beta } \\
\end{array}$} & \multirow[t]{2}{*}{$\mathrm{t}$} & \multirow{2}{*}{\multicolumn{3}{|c|}{ Sig }} \\
\hline & & B & Std. Error & & & & & \\
\hline \multirow[t]{2}{*}{1} & A & 1,233 & 2,797 & & 0,441 & 0,660 & & \\
\hline & $\mathrm{X} 1$ & .104 & 0,977 & 122 & 1.075 & .285 & 0,429 & 2.330 \\
\hline
\end{tabular}

Sumber: Hasil Analisis, 2020

Tabel 6 dapat dilihat bahwa nilai toleransi dari semua kemungkinan $>0,10$ dan VIF segala kemungkinan yang $<10.00$, yang ditandai dengan nilai toleransi terhadap para kepemimpinan dari 0429. Jadi itu adalah mungkin bahwa kemunduran dari model rumus tidak tidak memiliki multicore -problems atau dapat dikatakan bebas dari masalah multikolinearitas dan dapat digunakan dalam penelitian ini.

\section{4) Uji Hetereskedastisitas}

Tes heteroskedastisitas dalam satu regresi Model yang ketimpangan varians terjadi dari satu sampel ke yang lain. Jika perbedaan dari satu pengamatan ke pengamatan lainnya dengan pengamatan lainnya, dijuluki kelainan gay dan perbedaan itu disebut heteroskedastisitas. Model regresi yang baik adalah bahwa heteroseksualitas tidak terjadi ( Ghozali, 2011). Tes untuk mendeteksi adanya gejala heteroskedastisitas dilakukan dengan tes.

Tabel 7 Hasil Uji Heteroskedastisitas

\begin{tabular}{lcc}
\hline Membangun & Sig. & Kesimpulan \\
\hline X.Y & 0,660 & Heteroskedastisitas \\
\hline Sumber: Hasil Analisis, 2020 & &
\end{tabular}

Hasil uji heteroskedastisitas menggunakan statistik uji glasial diperoleh nilai semua variabel bebas (pemimpin transformasional) menjadi dependen (kinerja) lebih besar dari tingkat kesalahan 5\% $(0,05)$ sehingga dapat disimpulkan bahwa variabel penelitian bebas heteroskedastisitas.

\section{5) Tes Keamanan}

Keandalan adalah alat untuk mengukur kuesioner, sebagai indikator variabel atau konstruk. Sebuah kuesioner dikatakan dipercaya atau dipercaya sebagai jawaban bagi mereka yang dalam pernyataannya tidak konsisten atau tidak stabil dari waktu ke waktu. Kriteria uji yang dilakukan menggunakan yang Cronbach Alpha ( $\alpha$ ) tes . Variabel tersebut diyakini memberikan nilai Cronbach Alpha> 0,60 (Nunnaly, 1994 dalam Ghozali, 2011).

Tabel 8 Uji Normalitas

\begin{tabular}{|c|c|c|c|c|}
\hline \multicolumn{5}{|c|}{ Statistik Keamanan } \\
\hline \multirow{2}{*}{\multicolumn{2}{|c|}{$\begin{array}{c}\text { Alpha Cronbach } \\
0,960 \\
\end{array}$}} & \multicolumn{3}{|c|}{ N Item } \\
\hline & & & 33 & \\
\hline & $\begin{array}{l}\text { Skala Ke } \\
\text { Item } \\
\text { Dihapus }\end{array}$ & $\begin{array}{c}\text { Skala } \\
\text { Variasi Jika } \\
\text { Barang } \\
\text { Memotong }\end{array}$ & $\begin{array}{c}\text { Item yang } \\
\text { dikoreksi } \\
\text { - Jumlah } \\
\text { Korelasi }\end{array}$ & $\begin{array}{c}\text { Cronbach's } \\
\text { Alpha jika } \\
\text { Barang- } \\
\text { barang } \\
\text { terpotong }\end{array}$ \\
\hline 1 & 135.38 & 180.504 & 679 & 0,959 \\
\hline 2 & 135.46 & 178.986 & 704 & 0,959 \\
\hline 3 & 135.38 & 179.259 & .613 & 0,959 \\
\hline 4 & 135.26 & 180.767 & 602 & 0,959 \\
\hline 5 & 135.27 & 180.506 & 0,645 & 0,959 \\
\hline 6 & 135.37 & 180,420 & .655 & 0,959 \\
\hline 7 & 135.44 & 178.678 & .653 & 0,959 \\
\hline 8 & 135.37 & 179.747 & 0,538 & 0,960 \\
\hline 9 & 135.29 & 179.352 & 0,660 & 0,959 \\
\hline 10 & 135.36 & 179.622 & .735 & 0,959 \\
\hline 11 & 135,39 & 181.609 & 0,629 & 0,959 \\
\hline 12 & 135.35 & 179.374 & 673 & 0,959 \\
\hline 13 & 135.30 & 181907 & 573 & 0,959 \\
\hline 14 & 135.45 & 177.720 & 0,697 & 0,959 \\
\hline 15 & 135.31 & 179.666 & 0,623 & 0,959 \\
\hline 16 & 135.38 & 179.157 & .656 & 0,959 \\
\hline 17 & 135.42 & 178.369 & 663 & 0,959 \\
\hline 18 & 135,53 & 178.966 & .639 & 0,959 \\
\hline 19 & 135,52 & 178.456 & 647 & 0,959 \\
\hline 20 & 135.42 & 178.471 & 0,675 & 0,959 \\
\hline 21 & 135.45 & 179.046 & 672 & 0,959 \\
\hline 22 & 135.45 & 180.169 & 0,690 & 0,959 \\
\hline 23 & 135.61 & 178.139 & 0,776 & 0,958 \\
\hline 24 & 135,54 & 180.333 & 0,660 & 0,959 \\
\hline 25 & 135.47 & 178.987 & .710 & 0,959 \\
\hline 26 & 135.59 & 177.082 & 701 & 0,959 \\
\hline 27 & 135.61 & 177.139 & 0,694 & 0,959 \\
\hline 28 & 135.60 & 177.284 & 663 & 0,959 \\
\hline 29 & 135.68 & 177.221 & 0,690 & 0,959 \\
\hline 30 & 135,57 & 177.962 & 6771 & 0,959 \\
\hline 31 & 135.46 & 177.068 & .762 & 0,958 \\
\hline 32 & 135,53 & 178.844 & 0,536 & 0,960 \\
\hline 33 & 136.37 & 175.604 & 0,428 & 0,963 \\
\hline
\end{tabular}

Sumber: Hasil Analisis, 2020

Tabel 8 dapat diketahui bahwa semua variabel yang terkait dengan variabel independen (pemimpin) dapat diandalkan. Ini dapat dilihat dari positif nilai Cronbach 's alpha, masing-masing $0.959,0.959,0.960$, dan 0.963 lebih tinggi dari 0,60. Ini adalah dibayangkan bahwa semua pernyataan dalam penelitian ini adalah tinggi keaslian dan dapat digunakan dalam analisis di ini studi .

6) Tes Linearitas

Tes linearitas target untuk menentukan apakah dua variabel memiliki hubungan linier atau tidak signifikan. Tes ini digunakan untuk melihat apakah spesifikasi model yang digunakan sudah benar atau tidak ( Ghozali, 2011). Tes-tes ini biasanya digunakan sebagai prasyarat dalam 
analisis regresi linier. Dua variabel dikatakan memiliki hubungan linier jika signifikansi lebih besar dari 0,05 . Disimpulkan bahwa semua variabel independen yang konsisten dengan yang tergantung variabel. Ini bisa dilihat dari arti semua 0,05 di atas.

7) Analisis Linear Berganda

Hipotesis dalam penelitian ini diuji dengan menggunakan beberapa linear regresi model mengatakan bahwa regresi linier berganda digunakan untuk menguji pengaruh satu variabel dependen dan dua atau lebih variabel Ghozali (2013). Tujuan penerapan metode ini adalah untuk memprediksi atau memprediksi nilai variabel dependen yang dipengaruhi oleh variabel independen. Berikut ini ringkasan hasil beberapa uji regresi linier.

Tabel 9 Analisis Linear berganda

\begin{tabular}{cccccc}
\hline \multirow{2}{*}{ Model } & \multicolumn{2}{l}{$\begin{array}{l}\text { Unstandardized } \\
\text { Coefficients }\end{array}$} & $\begin{array}{c}\text { Standardized } \\
\text { Coefficients }\end{array}$ & \multirow{2}{*}{$\mathrm{t}$} & Sig \\
\cline { 2 - 4 } & $\mathrm{B}$ & Std. Error & Beta & & \\
\hline $\mathrm{A}$ & 1,233 & 2,797 & & 0,441 & 0,660 \\
$\mathrm{X} 1$ & .104 & 0,977 & 122 & 1.075 & .285 \\
& 0,035 & 0,082 & 0,042 & 0,432 & 0,667 \\
& 459 & 0,095 & 0,560 & 4,837 & .000 \\
\hline
\end{tabular}

Sumber: Hasil Analisis, 2020

Tabel 9, koefisien konstanta dan regresi dapat dibentuk menjadi:

$$
\mathrm{Y}=1.233+0.104 \mathrm{X} 1+0.035 \mathrm{X} 2+0.459 \mathrm{X} 3
$$

Dari rumus dari persamaan di atas dapat dijelaskan sebagai berikut:

a) Nilai tetap (a) adalah jumlah karyawan (Y). Variabel kepemimpinan dan kompetensi yang berkomunikasi secara konstan dengan nilai kinerja karyawan sebesar 1.233.

b) The $\mathrm{r}$ Koefisien penyimpangan dari yang kepemimpinan (X 1 ) dari 0104 ia mengklaim bahwa ada pengaruh antara kepemimpinan dan kinerja karyawan, kinerja karyawan kepemimpinan yang lebih baik yang akan menambah positif. Dima dan sebuah lebih baik kepemimpinan, semakin meningkatkan karyawan kinerja.

c) Koefisien dari komunikasi perlambatan global (X 2 ) dari 0,035 dan mengklaim bahwa ada komunikasi antara pengaruh kinerja karyawan jika karyawan lebih komunikasi, yang karyawan kinerja akan meningkat secara positif. Jika komunikasi lebih baik dan lebih baik, kinerja karyawan kami akan meningkat.

d) Koefisien regresi variabel (X 3 ) dari 0,459 kemudian menyatakan bahwa jika ada pengaruh antara kompetensi dan kinerja karyawan, kompetensi baik karyawan, yang karyawan kinerja akan meningkat secara positif. Di mana semakin banyak minat, semakin banyak kinerja meningkat dan keterlibatan karyawan .

8) Analisis Koefisien Determinasi

Koefisien determinasi (R2) adalah digunakan untuk menentukan kemampuan sebenarnya dari model untuk menjelaskan variasi dalam variabel dependen. Koefisien memutuskan (R2) adalah antara nol dan satu. Nilai mendekati satu berarti bahwa variabel independen menyediakan hampir semua informasi yang diperlukan untuk memprediksi variasi dalam variabel dependen (Ghozali, 2011). Hasil uji koefisien determinasi dapat ditemukan pada Tabel 10 berikut.

Tabel 10. Uji Koefisien Determinansi

\begin{tabular}{ccccc}
\hline Model & R & R Square & $\begin{array}{c}\text { Adjusted R } \\
\text { Square }\end{array}$ & $\begin{array}{c}\text { Std. Error of the } \\
\text { Estimate }\end{array}$ \\
\hline Performa & .682 & 0,465 & 0,449 & 0,25166 \\
\hline
\end{tabular}

Sumber: Hasil Analisis, 2020

Tabel 10 dapat dilihat bahwa penyesuaian $\mathrm{R} 2$ sebesar 0,465, dapat disimpulkan bahwa kepemimpinan transformasional, komunikasi, dan minat bersama mempengaruhi kinerja karyawan secara keseluruhan sebesar $44,9 \%$, dan masih $55,1 \%$ dipengaruhi oleh faktorfaktor selain dari variabel yang digunakan.

Hasil penelitian menunjukkan bahwa kepemimpinan transformasional memiliki pengaruh positif signifikan terhadap kinerja. Pengaruh kepemimpinan transformasional terhadap efek kinerja pada risalah Tucunan (2014) yang mengatakan bahwa kepemimpinan transformasional memiliki pengaruh terhadap kinerja karyawan . $\mathrm{T}$ ouch manusia menyatakan, transformasional kepemimpinan efek positif pada kinerja karyawan di PT penyamaran dengan mengambil pendekatan yang baik dan ramah kepada sehingga bawahan bawahan merasa senang dengan cara kepemimpinan arah dan input untuk dapat mencapai kinerja yang lebih baik. Alasan ini diperkuat oleh teori Robbins (2008) yang menggarisbawahi bahwa para pemimpin dapat mendorong bawahan mereka untuk berpikir kreatif dan inovatif.

Dari hasil penelitian yang dilakukan oleh peneliti, dapat dilihat bahwa karyawan memiliki masalah dengan yang transformasional kepemimpinan yang Harper Dengan Aston karyawan mengawasi . Hubungan antara kepemimpinan transformasional dan kinerja karyawan diperkuat dari hasil analisis regresi. Uji regresi menunjukkan hasil dalam Kepemimpinan global transformasional dalam kinerja sebesar 0,104 selain $\alpha=$ 0,05 toleransi kesalahan. Efek yang dihasilkan negatif dan signifikan, yang berarti bahwa kepemimpinan transformasional yang diadopsi oleh pemimpin karyawan telah menyebabkan menurunnya lapangan kerja. Hasil T test - note bahwa nilai yang dihitung adalah 1233. Hasil penelitian ini menunjukkan bahwa kepemimpinan transformasional memiliki pengaruh positif dan signifikan terhadap kinerja karyawan.

\section{SIMPULAN}

Kelengkap dan integral hasil penelitian bahwa pengaruh kepemimpinan yang baik akan memberikan dampak pada kinerja karyawan yang akan meningkat. 
Kepemimpinan transformasional memiliki pengaruh positif signifikan terhadap kinerja

\section{DAFTAR PUSTAKA}

Ahmad, N. A. R., Muhtar, M., \& Abubakar, H. 2020. Pengaruh Lingkungan Kerja, Kepemimpinan Dan Pengendalian Diri (Locus Of Control) Terhadap Kinerja Pegawai Melalui Kepuasan Kerja Di Dinas Kominfo Kabupaten Pangkep. Indonesian Journal of Business and Management, 2(1), 28-34.

Ackoff, Russel. 1999. The Design of Sosial Research. Jakarta : Penerbit Prenhalindo

Balasundaram Nimalathasan, 2005, Job Satisfaction and Employees' work Performance : A Case Study of People's Bank in Jaffna Penunsula, Sri Lanka.

Bass, 1985. Leadership and Performance Beyond Expectation. New York : Academic Press.

Bass, Bernard M. and Avolio, Bruce, J. (1993),"Transformational Leadership and Organizational Culture". $P A Q$, Spring.

Bass B.M.,\& Avolio B.J.,Berson Y.,Jung.D.I, (2003) Predicting Unit performance by Assesing Transformational and Transactional Leadership. Journal of Applied Psycology, 88(2) 207- 218

Bass, B.M. (1997). Does Transactional Transformational Leadership Paradigm Transcend Organizational and National Boundaries. Journal American Psychologist, 52: 130-139.

Ghozali, Imam. 2011. "Aplikasi Analisis Multivariate Dengan Program SPSS". Semarang: Badan Penerbit Universitas Diponegoro.

-------- 2013. Aplikasi Analisis Multivariate dengan Program IBM SPSS 21 Update PLS Regresi. Semarang: Badan Penerbit Universitas Diponegoro.

Gary Dessler Robbins dan Judge. 2018. Human Resource Management - 8th Edition.

Mangkunegara, Anwar Prabu. 2012, Manajemen SDM Perusahaan. Bandung:PT Remaja Rosdakarya.

Mundarti. 2007. Faktor-Faktor Yang Mempengaruhi Kinerja Dosen Dalam Melaksanakan Proses Belajar Mengajar Di Prodi Kebidanan Magelang Politeknik Kesehatan Semarang Tahun Akademik 2005 / 2006 (Tesis). PPs Undip Semarang

Sedarmayanti. 2007. Manajemen Sumber Daya Manusia. Bandung:PT Refika Aditama.

Yunxia Zhu, Pieter Nel, Ravi Bhat. 2006.Cross Cultural Study of Communication Strategies for Building Business Relationships. www.scholar.google.co.id. 